\title{
Perceptions of Effective Listeners: A Management Study
}

\author{
Judi Brownell \\ Cornell University
}

\begin{abstract}
Listening is a vital management skill. To find out more about how managers' listening is perceived in an organizational context, researchers administered a questionnaire to 144 managers and 827 of their subordinates in 6 hospitality organizations. Managers were asked to rate 26 of their own listening behaviors using a 7-point scale. Subordinates were asked to indicate their perceptions of their managers' listening behavior on each of the same 26 items. Profiles are presented of those managers who were perceived as particularly "good" or particularly "poor" listeners according to the ratings given them by their subordinates. Characteristics of those employees who gave their managers the highest and lowest ratings are also described. This information contributes to a better understanding of how managers' listening is perceived in organizational contexts.
\end{abstract}




\section{PERCEPTIONS OF EFFECTIVE LISTENERS: A MANAGEMENT STUDY}

Effective management requires effective communication. Many managers spend nearly 80 percent of their day engaged in some form of communication and, of that 80 percent, the greatest portion — some argue as much as 60 percent — is spent listening (Steil, Barker, \& Watson, 1983). But listening may be one of managers' least developed skills. Lyman Steil and his colleagues estimate that poor listening costs American business billions of dollars (Steil, Barker, \& Watson, 1983).

Business communication specialists have repeatedly noted the need for research in this field. In 1988, for instance, the Association for Business Communication Research Topics Subcommittee noted that the role of the sender in the communication process has been more widely researched than the role of the receiver, and that future research efforts might focus on receiver characteristics. The purpose of such a study, they explain, would be "... to determine those traits, characteristics, or behaviors that make certain individuals easier to communicate with.”

The purpose of this paper is to explore the characteristics of those individuals who are perceived by their subordinates as effective or ineffective listeners. Through a questionnaire, information was gathered regarding (1) hospitality managers' self-perceptions of their listening behavior and (2) subordinates' perceptions of their managers' listening behavior. The results of this study are presented, and the characteristics of those managers who received high and low ratings from their subordinates are identified. The individual variables that may be related to subordinates' perceptions of their managers' listening effectiveness are also reported. 


\section{COMMUNICATION IN THE ORGANIZATION}

During the past decade, increasing emphasis on human resource practices has reinforced the importance of effective managerial communication in satisfying employees’ needs, improving individual performance, and increasing organizational effectiveness (Dessler, 1983; Harrison, 1985; Eisenberg \& Witten, 1987). Communication and management specialists have come to look at the quality of work life largely in terms of the nature of the relationships that develop on the job (Dryer, 1985; Applebaum \& Anatol, 1979; Follert, 1980; Peters \& Austin, 1985; Barnes, 1981). Managers who view their role as one of coach and facilitator work to increase employees’ satisfaction, involvement, and commitment (Shea, 1984).

Specific managerial communication practices contribute to the development of this “facilitative” climate. Redding (1984) proposes that the ideal characteristics of the effective manager leader may well include a high degree of concern for others and responsiveness to perceived needs. Among the behaviors demonstrated by these managers are characteristics that are shared by effective listeners as well:

(a) empathizes with subordinates

(b) informs subordinates

(c) solicits ideas from subordinates

(d) creates an atmosphere where employees are rewarded for speaking out

(e) responds promptly and directly to employee concerns (pp. 93-95)

Effective managers are, therefore, those who express a sincere concern for the individual employee; they can be distinguished as those who listen (Klauss \& Bass, 1984; Keefe, 1971; Steil, Watson, \& Baker, 1983). 


\section{THE LISTENING PROCESS}

Managers are constantly required to listen; yet, researchers know less about listening than speaking, reading, or writing. Further research is needed to establish the exact nature of the listening process and provide direction for those seeking to improve individuals’ listening competence in organizational settings (Hunt \& Cusella, 1983; Mundale, 1980; Raudsepp, 1980).

Although listening activity is itself covert, most scholars agree that it requires a deliberate act - that listening is manifested by behaviors that can be learned and improved. Consequently, those interested in training have looked for ways to approach listening, instruction from a behavioral perspective (Brownell, 1986). If listening is vital to effective management practice, business communication scholars need to know exactly what managers must learn to "do" to increase their effectiveness. In many organizational contexts, the perception of effective listening is vital. Managers and their service employees must be perceived as good listeners by their audiences. When employees say their manager “doesn’t listen,” it is essential to know what this means. If specific indicators can be identified, then management educators and trainers are in a much better position to specify objectives, design course content, and select appropriate instructional methods and activities. If human resource professionals have clear performance criteria, assessment measures can be designed to identify individuals who are or who have the potential to become exceptionally good listeners.

\section{THE SIX-COMPONENT HURIER MODEL}

The present study is based on a model that was developed in response to a need for more precise information about managers' and subordinates' perceptions of listening behavior. After careful examination of the existing literature and a review of the standardized tests most 
frequently used to assess listening competence (Watson \& Barker, 1984; Brown \& Carlson, 1955; Bostrom, 1983), a list of specific listening behaviors was generated. A conceptual framework was then developed for clustering these listening behaviors into six general areas. These areas represented the major aspects of listening behavior presented in the literature to date, with emphasis on those aspects identified by Ralph Nichols (1956), Larry Barker (1971), James Floyd (1985), and Lyman Steil and his colleagues (1983). The theoretical framework this author used to study managerial listening is called the HURIER model (Brownell, 1985).

The HURIER model suggests that elements of the listening process, although interrelated, can be approached as separate skill areas. Rather than viewing listening as a unitary, covert process (Weaver, 1972; Sperritt, 1962), the HURIER model focuses on the indicators individuals use to make judgments about listening effectiveness and clusters these indicators into general areas or components, as follows: Hearing, Understanding, Interpreting, Evaluating, Remembering, and Responding.

Since the HURIER model draws attention to specific indicators of listening effectiveness, the model can reasonably be used as a basis for gathering information regarding the perceptions of managerial listening behavior.

\section{A PROFILE OF GOOD AND POOR LISTENERS}

A 26-item questionnaire was developed and administered to middle managers and their subordinates in six hospitality organizations. Usable questionnaires were received from 144 managers and 827 of their subordinates. Responses to this questionnaire were analyzed and a profile of "good" and "poor" listeners was developed on the basis of subordinates' ratings of 
their managers' listening behaviors. The variables that were associated with subordinates' perceptions of their managers' listening behaviors were also examined.

\section{Method}

Questionnaire items were generated in a number of ways. First, a comprehensive literature search (1950-1987) revealed articles and books that were then reviewed to determine recurring behavioral concerns associated with effective or ineffective listening such as "interrupting," "not remembering," "use of jargon," "reinforcing to nonverbal cues," and the like. Although most of these behaviors were taken into account in the development of the original HURIER model, it was essential to generate a wide range and comprehensive list of specific listening behaviors. Listening assessment instruments (the Barker-Watson Listening Test, the Brown-Carlson Listening Text, the Kentucky Comprehensive Listening Test) were again surveyed to identify areas of concern and to ensure a comprehensive list of behaviors measured on standardized listening tests. Finally, the specific items to be used in the questionnaire were stated as distinct listening-related behaviors.

A 59-item questionnaire was piloted on 102 managers and 731 of their colleagues in a public utilities company. Middle managers from all functional areas were asked to rate their behavior on each of 59 separate items. Companion questionnaires were distributed to at least five of the manager's colleagues/subordinates.

Data were analyzed, and the instrument was revised in light of findings from this pilot study. The new 26-item questionnaire was then administered to department heads and mid-level supervisors at seven hospitality organizations. Since middle managers serve as key links in numerous formal and informal communication networks, their listening effectiveness can be 
assumed to have a direct impact on their organization. Managers were asked to indicate, on 7point scales, the degree to which they believed they displayed each of 26 listening-related behaviors on the job.

A Subordinate Questionnaire was distributed in-house through the General Manager or the Training and Development Department to each manager's subordinates. These subordinates were asked to rate their managers on the same 26 items, providing their perceptions of the manager's listening behaviors on coded questionnaires. Only managers supervising more than five individuals were included in the study. This was done to increase the validity of the results and to obscure each subordinate's identity.

Although questionnaires were distributed in-house, they were coded and returned directly to the researcher in sealed envelopes. After the data were analyzed, managers received information that enabled them to compare their self-perceptions of each listening behavior both with their colleagues' perceptions and with the self-perceptions of other managers. Since both managers' and subordinates' questionnaires were completely anonymous, the study provided nonthreatening but specific information on each manager's behavior. This feedback not only directs managers as they work to improve their listening, but it also provides the organization with useful information for future training and development efforts.

In addition to rating specific listening behaviors, background information was requested from both the managers and their subordinates. This information was gathered to identify any significant relationships between either the manager's self-perceptions of his or her listening behavior or the subordinates' perceptions of the managers' listening behavior and variables such as gender, age, time in current position, and prior listening training. The following section summarizes these findings. 


\section{The Good Listeners: Who Are They?}

A clear profile emerges when the sample of managers is divided into quartiles according to how subordinates perceived their manager’s listening behavior. For each manager, a sum score was computed for each subordinate's rating and a mean rating of 5 or more subordinates was subsequently calculated for each manager. The following discussion examines managers who received subordinate ratings that placed them in either the top or the bottom quartile; that is, "good listeners" are those 36 managers who were given high enough ratings by their subordinates that they fell into the top 25 percent of the sample. The 36 "poor listeners" are managers whose subordinates' ratings placed them in the bottom 25 percent of the sample. Managers' self-ratings were not considered in this analysis.

Out of a possible 7 points, good listeners' had mean scores of 5.8 - 6.6 while the subordinates of poor listeners assigned ratings that resulted in means of from 3.6 - 4.9. Comparisons between these two groups on a number of independent dimensions (Table 1) reveal some interesting differences. The dimensions were chosen on the basis of their theoretical interest and relevance to communication and human resources management.

Table 1. Good and Poor Listeners: Managers’ Profiles

\begin{tabular}{lccc}
\hline Variables & Percent of Total & $\begin{array}{c}\text { Percent of First } \\
\text { quartile }\end{array}$ & $\begin{array}{c}\text { Percent of } \\
\text { Fourth quartile }\end{array}$ \\
\hline Gender & 63 & & 64 \\
Male & 37 & 58 & 36 \\
Female & & & \\
Age & 4 & 3 & 3 \\
Under 24 & 49 & 75 & 19 \\
$24-34$ & 20 & 8 & 22 \\
$35-44$ & 23 & 14 & 47 \\
$45-54$ & &
\end{tabular}


Over 54

Time in Position

Under 6 months

6 mon -1 yr

1 - 2 years

3-5 years

6-10 years

over 10 years

Training

Yes

No

Satisfaction with Position

Very satisfied

Satisfied

Neutral

Somewhat dissatisfied

Dissatisfied

Managers Self-Rating

Very Good

Good

Fair

Poor

Very Poor

\section{0}

8

1

31

6

31

28

8

19

8

0

58

11

42

89

(n)

9

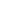

8

6

1

8

11

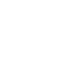

$25 \quad 6$

$58 \quad 69$

$17 \quad 22$

0

0

$33 \quad 6$

$61 \quad 88$

6

0

0

\section{Gender}

Of the total study population (144 managers), 63 percent of the managers were male and 37 percent female. It is interesting to note, therefore, that while the percentage of males and females placed in the bottom quartile closely reflected the percentage distribution within the total population, the percentage of women managers perceived as particularly effective listeners was greater than the percentage of men. 


\section{Age}

The hospitality managers studied appear to be a relatively young population, with the majority of subjects between the ages of 24 and 34. It appears, however, that managers over 45 years were given slightly lower ratings than their younger colleagues. Although only 27 percent of the subjects were over 45 , they accounted for 55 percent of the managers who received the lowest ratings by their subordinates. Several other recent studies (M. Gilbert, 1989; Husband, 1987; Brownell, 1988) have presented similar findings.

\section{Number of Years in Current Position}

There also appears to be a tendency for managers who have held their positions a shorter amount of time (regardless of how long they have been working at the particular properly) to be perceived by their subordinates as better listeners than managers who have been in the same position for over 6 years. Sixty-seven percent of the managers surveyed had held their current position between 6 months and 2 years. Of those placed in the top quartile by their subordinates, 60 percent fell into this category. The composition of the bottom quartile was similar, with 57 percent of the 36 managers in this group having held their position between 6 months and 2 years.

A pattern worthy of note occurs on the extreme ends of the "time in position" category. While 11 percent of the total manager population had been at their job fewer than six months, this group accounted for 31 percent of the "good listeners" and only 6 percent of the "poor listeners.” At the other extreme, 12 percent of the manager population had been in their current position more than 6 years, but these managers accounted for 27 percent of the managers placed 
in the bottom quartile by their subordinates. Only two managers from this group were among the "good listeners."

\section{Participation in Listening Instruction}

Managers were asked whether they had participated in a seminar or course in listening within the last five years. Of the 144 managers questioned, nearly half (43 percent) reported that they had experienced some form of listening instruction. A closer examination of the findings reveals that a greater percentage of managers who had not had any listening training was given ratings that placed them in the bottom quartile of the manager population than managers who indicated they had attended a listening course or seminar. Eighty-nine percent of the managers who were in the bottom quartile had not had any previous listening training, compared to 42 percent of those in the top quartile.

\section{Satisfaction with Position}

Both managers and their subordinates were asked how satisfied they were with their current position. Here, the managers' responses are examined. While 13 percent of the total manager population expressed either neutrality or some degree of dissatisfaction with their position, higher percentages were found in the top and bottom quartiles than in the rest of the management population. The most striking difference, as might be predicted, was found in the bottom quartile where almost twice as many managers — 25 percent of the group — indicated that they were either "neutral” or "somewhat dissatisfied" with their job.

Unlike other groups of managers studied (Brownell, 1988), not one of the 144 hospitality managers described himself or herself as a "poor" listener. Ninety-four percent of the subjects in 
this study perceived themselves as "good" or "very good” listeners! Since half of the managers in the bottom quartile received mean subordinate ratings of less than 4.3 on a 7-point scale, the findings suggest a significant discrepancy among managers in the bottom quartile between their self-perceptions and the perceptions subordinates have of their listening skills.

A closer examination of managers in the bottom quartile reveals 94 percent of this group gave themselves ratings of "very good" or "good"; only two of these managers thought their listening ability was "fair." On the other side, 33 percent of the 36 managers placed in the top quartile identified themselves as "very good" listeners, compared to 6 percent of those in the bottom quartile and 29 percent of the total manager population. It appears, then, that while individuals perceived as exceptionally good listeners recognize their ability, those who listen less effectively (as judged by their subordinates) are unaware that others are experiencing some degree of dissatisfaction with their listening behaviors. The next task involves an examination of the employees whose judgments were used to classify managers into "good" or "poor" listener groups.

\section{Subordinate Profiles:}

\section{Who Gives Managers High and Low Ratings?}

Now that the characteristics of managers whose subordinates gave them particularly high or low ratings have been examined, the variables that affect subordinates' perceptions of their managers' listening behavior are examined. Each subject in the pool of 827 subordinates was rated according to the mean of his or her responses on the 26 items concerning the manager's listening behavior. Once again, top and bottom quartiles were identified. The 207 individuals 
who gave their managers the highest ratings are compared to those who assigned ratings that fell into the lowest quartile.

When the data are examined (Table 2), three factors appear particularly interesting and reinforce findings of an earlier study that examined the same questions (Brownell, 1988). The three variables include:

(a) degree of familiarity with the manager

(b) frequency of communication with the manager, and

(c) subordinates' satisfaction with their job and with their relationship with the manager.

\section{Familiarity with Manager}

We see in Table 2 that those subordinates who gave their managers high ratings on their listening behaviors also tended to report knowing their managers "very well” (59 percent). Those who assigned lower ratings to their manager's listening behaviors were also more likely than their peers to report not knowing him or her very well. While 11 percent of the total subordinate population and 3 percent of those who gave their manager the highest ratings indicated that they did not know the manager well, 20 percent of the subordinates who assigned the lowest ratings indicated that they were not very familiar with their manager.

\section{Frequency of Communication with Manager}

Frequency of communication, too, appears to be linked with subordinates' perceptions of their managers' listening behavior. It seems that the more frequently these individuals communicate with their manager, the more likely they are to view this person as a good listener. 
Sixty-four percent of those whose ratings placed their manager in the top quartile indicated that they communicated "very frequently" with this person, while only 18 percent of the subordinates who assigned poor ratings reported that they interacted with their manager that often.

\section{Table 2. Factors That Influence Subordinates’ Profiles}

\begin{tabular}{|c|c|c|c|}
\hline Variables & $\begin{array}{l}\text { Percent of } \\
\text { Total }\end{array}$ & $\begin{array}{c}\text { Percent of First } \\
\text { Quartile }\end{array}$ & $\begin{array}{c}\text { Percent Fourth } \\
\text { Quartile }\end{array}$ \\
\hline \multicolumn{4}{|c|}{ Familiarity with Manager } \\
\hline Very familiar & 37 & 59 & 34 \\
\hline Fairly familiar & 52 & 38 & 46 \\
\hline Not very familiar & 11 & 3 & 20 \\
\hline \multicolumn{4}{|c|}{ Frequency of Communication } \\
\hline Very frequent & 29 & 64 & 18 \\
\hline Frequent & 50 & 29 & 32 \\
\hline Occasional & 12 & 7 & 32 \\
\hline Seldom & 9 & +0 & 18 \\
\hline \multicolumn{4}{|l|}{ Satisfaction with Job } \\
\hline Very satisfied & 28 & 47 & 33 \\
\hline Satisfied & 56 & 44 & 45 \\
\hline Dissatisfied & 16 & 9 & 22 \\
\hline Very dissatisfied & 0 & 0 & 0 \\
\hline \multicolumn{4}{|c|}{ Satisfaction with Relationship } \\
\hline Very satisfied & 25 & 57 & 14 \\
\hline Satisfied & 63 & 42 & 52 \\
\hline Dissatisfied & 11 & 1 & 30 \\
\hline Very dissatisfied & 1 & 0 & 3 \\
\hline
\end{tabular}

In fact, half of the subordinates who gave their managers the lowest ratings indicated on their questionnaires that they communicated only "occasionally" or "seldom” with their 
managers. This can be compared to 7 percent of the subordinates who were among those giving their managers the highest ratings.

\section{Satisfaction and Perceptions of Listening Ability}

Finally, we see that the subordinates' satisfaction with both the job and his or her relationship with the manager differs between the highest and lowest quartile groups.

Of those subordinates whose ratings of their managers placed them in the lowest quartile, 22 percent indicated dissatisfaction with their job and 33 percent indicated some degree of dissatisfaction with the subordinate-manager relationship. The picture changes, however, for the quartile group assigning the highest manager ratings. Here, we find that 91 percent were satisfied with their jobs while 205 of the 207 subordinates in this group were satisfied or very satisfied with their relationship with their manager. These data are consistent with the common sense notion that a link exists between a subordinate’s satisfaction with work-related variables and his or her perceptions of the manager's listening.

\section{CONCLUSION}

The results of this study give management scholars clues as to how individuals perceive listening and tell us something about the characteristics both of good listeners and of those who are most likely to view their managers as good listeners. Although the findings presented here relate to one sample population, this information is useful in our efforts to better understand the nature and role of listening behavior as it is perceived by managers and their subordinates in an organizational context. Although women accounted for just over one-third of the total management group, they made up over half of the highly rated listener population, Why? 
Although any conclusions at this point are speculative, previous research has confirmed that women are more outwardly expressive than men; they externalize emotions and provide stronger nonverbal cues than do their male counterparts. The fact that women visually demonstrate their response through eye contact, head nods, smiling, and other positive affects likely contributes to perceptions of attentiveness, interest, empathy, and subsequent listening effectiveness (Buck, Miller, \& Caul, 1974; Hall, 1984).

Findings of this study support earlier research and suggest that managers over 45 years old are perceived as poorer listeners than their younger counterparts. One explanation for this finding may be that older workers are more satisfied with their present position (Hunt \& Saul, 1977) and therefore tend to be more passive as well. Since motivation is one of the key factors in listening effectiveness (Petrie, 1961), the older worker may be less inclined to seek new information than younger employees who are still actively climbing the career ladder. Another explanation of these results may be that because the subordinate population represents a particularly young group (mean age of 28), they tend to perceive those who are older and less like themselves as poorer listeners.

Perhaps individuals who have held their current positions less than one year, regardless of how long they have been a member of the organization, may be more conscious of their listening behavior and are consequently perceived by their colleagues as more effective listeners. Are these "better listeners" simply trying harder? Or are good listeners more likely to advance within their organizations and experience job changes more frequently? Job enrichment, one of many quality of worklife strategies, requires individuals to assume additional responsibilities. Would this change spur individuals to listen more effectively — to try harder to listen well because they perceive a greater need to familiarize themselves with a new situation? Further research may 
reveal answers to these questions as communication scholars work with human resource professionals to identify effective ways to motivate and recognize employee performance.

Individuals who have had some listening training are, it seems, somewhat more likely than their peers to be given high ratings by subordinates. A more striking finding, however, is the high percentage of managers in the bottom quartile who had not had any training in the subject. One suggested hypothesis is that managers who have not given any prior thought to their listening are not behaving in ways that create the perception of "good listening." Since awareness and motivation can make a difference in listening behavior (Weaver, 1972; Beatty, Behnke, \& Froelick, 1980), it is safe to assume that regardless of the extent and nature of the prior listening training, it could have raised participants' consciousness of their behaviors and, subsequently, more appropriate listening behaviors were demonstrated by the managers and perceived by subordinates as indicators of effective listening.

Another interesting finding concerns the degree to which managers' self-perceptions of their listening effectiveness corresponded to their subordinates’ ratings. Self-perceptions are assumed to be accurate when those managers placed in the top quartile describe themselves as "very good" or "good" listeners, and when the managers in the bottom quartile choose "poor" or "very poor” to describe their listening effectiveness. It was, then, unsettling to discover that virtually all managers in this sample perceived themselves as "very good" or "good” listeners (a small percentage placed themselves in the "fair" category) even though those managers in the bottom quartile received mean ratings as low as 3.6 from their subordinates ( 3 indicates that an effective listening behavior is demonstrated "infrequently").

These data clearly suggest a discrepancy between managers' self-perceptions and the perceptions their subordinates have of their listening behavior. Accurate self-perceptions are 
essential not only for the long-term effectiveness of training efforts but also for the managers' own personal and professional development (Argyris, 1982). It is evident, therefore, that direct and frequent feedback is necessary for managers to align their self-perceptions with the impressions others have of their behavior. With regard to listening, the findings indicate that hospitality managers may be overconfident of their listening ability.

Turning to look at the profile of those subordinates who assigned their managers particularly high and particularly low ratings, it appears that subordinates' perceptions of their managers' listening behaviors are related to at least three variables: (1) their familiarity with their manager, (2) the frequency of manager-subordinate communication, and (3) the subordinate's satisfaction both with his or her job and with the manager-subordinate relationship. Whether effective listeners cause subordinates to feel more familiar, communicate more frequently, and increase their satisfaction is unclear; it is reasonable to assume, however, that managers who listen well encourage rather than discourage these responses. It might also be hypothesized that subordinates who know their manager well are more willing to overlook deficiencies in their listening behavior.

The more we learn about listening, the more apparent our research needs become. As more is learned about how listening is perceived, and as the components of the listening process are more clearly specified, communication specialists and practitioners alike will be better able to assess and develop managers' listening ability. If managers are to be perceived as good listeners — and research indicates that this is desirable — then this study contributes to the growing body of information educators can use in the training and development of future business leaders. 


\section{REFERENCES}

ABC Research Topic Subcommittee. (1988). Research topics in business communication. The Bulletin, 60(2), 32-39.

Applebaum, R.I., \& Anatol, K.W.E. (1979). An examination of the relationship between job satisfaction organizational norms, and communication climate among employees in an organization. Paper presented at a meeting of the Communication Association of the Pacific, Honolulu. Reported in R. Wayne Pace (1983). Organizational communication: Foundations for human resource development. Englewood Cliffs: Prentice Hall, Inc.

Argyris C. (1982). Reasoning learning, and action: Individual and organizational. San Francisco: Jossey Bass, Inc.

Barker, L. (1971). Listening behavior. Englewood Cliffs: Prentice Hall, Inc.

Barnes, L.B. (1981). Managing the paradox of organizational trust. Harvard Business Review, 59, 107-116.

Beatty, M.J., Behnke, R.R., \& Froelich, D.L. (1980). Effects of achievement incentive and presentation rate on listening comprehension. Quarterly Journal of Speech, 66,193-200.

Bostrom, R. (1983). The Kentucky Comprehensive Listening Test. Lexington: Listening Research Center.

Brown, J.I., \& Carlsen, G.R. (1955). Brown-Carlson Listening Comprehension Test. New York: Harcourt, Brace and World.

Brownell, J. (1986). Building active listening skills. Englewood Cliffs: Prentice Hall, Inc.

Brownell, J. (1985). A model for listening instruction: Management applications. ABCA Bulletin, 48(3), 39-44. 
Brownell, J. (1988). Perceptions of listening behavior: A management study. Working Paper. Cornell University, School of Hotel Administration, Ithaca.

Buck, R., Miller, R.E., \& Caul, W.P. (1974). Sex, personality, and physiological variables in the communication of affect via facial expression. Journal of Personality and Social Psychology, 30, 587-596.

Dessler, G. (1984). Human behavior: Improving performance at work. Reston, VA: Prentice Hall, Inc.

Dreyer, R.S. (1985). Feelings. Supervision, 47, 11-13.

Eisenberg, E.M., \& Witten, M.G. (1987). Reconsidering openness in organizational communication. Academy of Management Review, 12, 418-426.

Floyd, J. (1985). Listening: A practical approach. Glenview, IL, Scott, Foresman and Company.

Follert, V. (1980). Communication climate: A theoretical framework for accessibility. Journal of Applied Communications Research, 1, 91-100.

Gilbert, M. (1989, March). Perceptions of listening behaviors of school principals. Paper presented at the International Listening Association Convention, Atlanta, Georgia.

Hall, J. A. (1984). Nonverbal sex differences: Communicating accuracy and expressive style. Baltimore: Johns Hopkins University Press.

Harrison, T.M. (1985). Communication and participative decision making: An exploratory study. Personnel Psychology, 38, 93-116.

Hunt, G.T., \& Cusella, L.P. (1983). Afield study of listening needs in organizations. Communication Education, 32, 393-401.

Hunt, J., \& Saul, P. (1975). The relationship of age, tenure, and job satisfaction in males and females. Academy of Management Journal, 18,691-702. 
Husband, R. (1987, March). Assessing manager and subordinate perceptions of managerial listening behavior. Paper presented at the International Listening Association Convention, New Orleans.

Keefe, W.F. (1971). Listen management. New York: McGraw Hill, Inc.

Klauss, R., \& Bass, N.M. (1982). Interpersonal communication in organizations. New York: Academic Press.

Mundale, S. (1980). Why more CEO’s are mandating listening and writing training. Training, 17, 37-41.

Nichols, R.G. (1956, July). Listening is a 10-part skill, Nations’ Business, p. 45. Peters, T., \& Austin, N. (1985). A passion for excellence: The leadership difference. New York: Warner Communications Company.

Petrie, C.R., Jr. (1966). The listener. In S. Duker (Ed.), Listening readings (pp. 333-349). New York: The Scarecrow Press, Inc.

Raudsepp, E. (1980). Increase your effectiveness: Learn to listen. Journal of Applied Management, 5, 21-23.

Redding, W.C. (1984). The corporate manager's guide to better communication. Glenview: Scott, Foresman and Company.

Shea, G.F. (1984). Building trust in the workplace. New York: American Management Association.

Sperritt, D. (1962). Listening comprehension: A factorial analysis. Melbourne: Australian Council for Educational Research.

Steil, L., Barker, L., \& Watson, K. (1983). Effective listening: Key to your success. New York: Addison Wesley Publishing Company. 
Watson, K., \& Barker, L. (1984). Watson-Barker Listening Test. New Orleans: Spectra, Inc. Weaver, C. (1972). Human listening: Process and behavior. Indianapolis: Bobbs Merrill, Inc. Wolvin, A.D., \& Coakley, C.C. (1987). Listening. Dubuque: William C. Brown Company. 